\title{
EDITORIAL
}

\section{IN MEMORIAM: BERNARD LONERGAN AND KARL RAHNER}

The summer I spent studying Bernard Lonergan's Insight was probably the highlight of my exposure to philosophy. For the first time I experienced how and why intelligence was not something merely objective, outside of me, but rather something constitutive of being human, of my self. Quite parallel was the year I spent studying Karl Rahner's Theological Investigations. I was supposed to be studying tracts on the Church, introductions to Scripture, and the rudiments of moral theology, but there was no way I was going to leave the nourishment, the upbuilding of faith, that Rahner was providing. By the venerable standards of contemplative prayer, which said that one should remain with what was feeding one's soul, I felt obliged as well as thrilled to be pondering the real mysteries of grace.

Lonergan and Rahner have now both gone to God, as nearly equal in their leaving this life in 1984 as they were in beginning it in 1904. Quite literally around the world, they have left thousands permanently in their debt. Many of these thousands, like me, would scarcely know how to configure their faith, apart from the guidance of "Bernie" and "Father Rahner." Within a tradition that always threatens heteronomy, they have shown a way of the mind and the heart that summons all the authenticity any of us can muster. So let us now praise these two famous men, and keep them fresh in our prayers.

I think first of Lonergan, because he was the first one who made the Johannine reflections on the circumincession of the divine persons real for me. No doubt this is not the service Lonergan performed for most of his disciples, but we each catch on as we can. I found the "Verbum" articles simply stunning, because they really showed how the intelligible emanation of word from act of insight was a worthy image of God, a fitting analogy. The same with the procession of love from judgment, as Fred Crowe later elaborated it more fully. The experiential richness in which these analogies bathed, their rootage in primal human spirituality, meant no absent God, nothing of that almost bathetic "missingness" that was afflicting the Continent or "death" that was reputed to have occurred at home. Despite all our murkiness, God could be light in whom there was no darkness at all. No matter how fierce our resistance to development, our clinging to the surdity of sin, God could be pure love. Unlike some of my fellow students of Lonergan, I never found these matters impossibly abstract. On the contrary, the thrilling thing was reading a teacher who could point you to exactly where the symbols of faith drew their experiential origins-and then show you what purifications were the next task. 
Something similar occurred for me with Karl Rahner. Theology was supposed to be coherent, if not systematic, but on my own I mainly found bits and pieces. Only by settling in with Rahner, signing on for the long haul, did something of the blessed simplicity of Catholic Christian faith begin slowly to come into focus. If you pressed Rahner, he could put it all in a single article. If you pressed him some more, he could put it in a single phrase: "God gives himself." When Christology took center stage, Rahner had the sense of symbol and the respect for Jesus' uniqueness that made the Incarnation both something in keeping with our human outreach to God and something it had never entered the human heart to conceive, at least to this extreme of love. When Church matters begged attention, Rahner could speak of the definitive eschatological community of salvation-and only a little study was necessary to make these words absolutely pregnant. More and more, however, I came to sense that Mystery and Grace were the Rahnerian key words. The one brought a hush, so that the mind as well as all mortal flesh kept silence. The other was like cadenzas of praise packed in the most humble insight or event, waiting to burst forth and imitate the Cherubim. For me personally, the contemplation to obtain divine love always came to mind, as though Rahner's schooling in The Spiritual Exercises had riveted him to the threshold between the Crucified and the Giver of the Spirit of peace and joy.

So Rahner and Lonergan pass before my mind, continue to fill thousands and thousands of hearts, for the intelligence and faith and love that shone forth from them. Among all us saints, all people called to share in the wonders of the divine mystery of warmth and light, they have been extraordinarily helpful. If people now want to know how to love God wholeheartedly, without fleeing their minds or their hearts, their bodies or their communities, we need only offer them the elucidations of the gospel and the mystery of life that Bernard Lonergan and Karl Rahner have produced. If people want to know, in this our time, what a genuine Christian intellectual is like, we have tough, real, challenging, unsanitized, very lovable exemplars to show them. In the light in which they now abide, Karl Rahner and Bernard Lonergan need no longer be embarrassed by this reverence. They have much more absorbing occupations. For (as Rahner explicitly told an audience at the University of Chicago, convened for the 700th anniversary of the death of Aquinas), even in heaven one does not exhaust the mystery of God.

-JOHN CARMODY 